\title{
In vitro effect of seven antiparasitics on Acolpenteron ureteroecetes (Dactylogyridae) from largemouth bass Micropterus salmoides (Centrarchidae)
}

\author{
Renate Reimschuessel ${ }^{1}$, Charles Gieseker ${ }^{1, *}$, Sarah Poynton ${ }^{2}$ \\ ${ }^{1}$ US Food and Drug Administration, Center for Veterinary Medicine, Office of Research, 8401 Muirkirk Road, Laurel, \\ Maryland 20708, USA \\ ${ }^{2}$ Department of Molecular and Comparative Pathobiology, Johns Hopkins University School of Medicine, Room 811, \\ Broadway Research Building, 733 North Broadway, Baltimore, Maryland 21205, USA
}

\begin{abstract}
Few drugs are approved by the United States Food and Drug Administration for treating parasite infections in minor species such as fish, due in part to the high cost of developing such drugs and to a relatively small market share for drug sponsors. Because in vivo effectiveness trials for antiparasitic drugs are costly, time consuming, and use many animals, a systematic in vitro screening approach to describe parasite motility could help find promising drug candidates. We evaluated the effects of 7 antiparasitics on the activity and survival of the endoparasitic monogenean Acolpenteron ureteroecetes (Dactylogyridae) collected from the posterior kidneys of juvenile largemouth bass Micropterus salmoides (Lacepede, 1802) (Centrarchidae) held in the laboratory. Tests were conducted in 12 well tissue culture plates; each well had 3 parasites, and we tested 3 concentrations and 1 control for each of the 7 antiparasitics. The parasites were observed immediately after adding the drug, at 1 to $3 \mathrm{~h}$, and 17 to $26 \mathrm{~h}$, and video recordings were made. Drug effects were recorded by documenting morbidity (reduced movement, tremors, contracted body, abnormal morphology) and mortality. A. ureteroecetes was strongly affected by the quinoline praziquantel, the imidazothiazide levamisole, and the organophosphates dichlorvos and trichlorfon. The parasites were moderately affected by the macrocyclic lactones ivermectin and emamectin, and generally unaffected by the benzimidazole mebendazole. Our study demonstrates the utility of characterizing in vitro responses with video microscopy to document responses of fish parasites for initial screens of drug effects on a fish monogenean.
\end{abstract}

KEY WORDS: Parasite $\cdot$ Largemouth bass $\cdot$ In vitro $\cdot$ Antiparasitic $\cdot$ Bioassay

\section{INTRODUCTION}

Aquaculture in the USA has grown into a billion dollar per year industry (USDA 2006). However, despite this growth, domestic aquaculture is still a relatively small segment of US agriculture, and thus is a small market for US Food and Drug Administration (USFDA)approved drugs. Because of this minimal incentive, and the high cost for the pharmaceutical industry to develop drugs for aquaculture species, there are only 7 drugs approved for farmed fish in the USA. As a result, Congress enacted the Minor Use and Minor Species (MUMS) Animal Health Act in 2004, to establish new regulatory procedures intended to make more medications legally available for the treatment of minor animal species, (meaning species other than major agriculture and companion animals). In response to MUMS, USFDA has conducted a number of studies to 
support the development and availability of drugs to treat bacterial and parasitic infections in minor species.

Parasitic diseases are a significant problem for aquaculture, and can cause morbidity and mortality at all stages of the production cycle. In the USA, only 1 drug is approved by the USFDA (i.e. formalin, with 4 USFDA-approved compounds: Parasite-S, Formalin-F, Formacide-B, and Paracide-F) for control of certain external parasites (ectoparasitic flagellates, ciliates, and monogeneans) on fish, and no drugs are approved for use against internal parasites in fish. This situation is in sharp contrast to that for mammals, for which there are many drugs approved for external and internal parasites. Some antiparasitic drugs approved for mammals may be useful for aquaculture species.

The USFDA, in conjunction with the International Cooperation on Harmonization of Technical Requirements for Registration of Veterinary Medicinal Products, (VICH), provides guidance documents detailing the methods that should be used to evaluate parasiticides in studies used to support drug approvals in terrestrial animals. However, the USFDA does not currently provide comparable guidance for parasiticides in fish. Our present study is part of a larger effort by USFDA scientists to develop guidelines to evaluate antiparasitic treatments for fish.

We chose to work with the endoparasitic monogenean Acolpenteron ureteroecetes Fischthal and Allison, 1940, found in the ureters and kidneys of largemouth bass Micropterus salmoides (Fischthal \& Allison 1941), because it can easily be propagated in the laboratory (Gieseker et al. 2007). The adult parasite lives in the ureters, passing eggs which can remain in the kidney or be passed out in the urine. The eggs hatch and the larvae can infect new fish or reinfect the original host. Although the infection in wild fish is typically of low density (Fischthal \& Allison 1941), in closed aquaculture systems, heavy $A$. ureteroecetes infections lead to losses of juvenile bass (DuPlessis 1948, PetrieHanson 2001).

In our previous laboratory experiments, we documented the gradual development of the infection over 3 to $4 \mathrm{mo}$, and the subsequent plateau of high prevalence and high density infection (Gieseker et al. 2007). Because of its gradual progression, Acolpenteron ureteroecetes has the potential to be a suitable in vivo model of monogenean infection, since drug effects at different stages of the infection can be investigated. The laboratory system we established also allowed us to develop methods to collect and maintain A. ureteroecetes in vitro for up to $30 \mathrm{~h}$, allowing ample time to evaluate treatment effects.

The present in vitro study was designed to (1) develop a bioassay for in vitro testing of antiparasitics using the endoparastic monogenean Acolpenteron ureteroecetes, and (2) use the bioassay to determine the effect of 7 different antiparasitics on activity and survival of this parasite. The compounds represented 1 quinoline, 1 imidazothiazide derivative, 2 organophosphates, 2 macrocyclic lactones and 1 benzimidazole. These compounds were used because they have been reported to be useful for treating fish parasites, and have been listed in veterinary formularies (Stoskopf 1993, Noga 1996, Lewbart 2005). Supplemental materials in the form of video captured motion pictures are available at www.int-res.com/articles/ suppl/d094p059_supp/ to demonstrate the effects of the antiparasitic drugs. These videos were evaluated by observation of motion (normal or abnormal/ reduced, tremors or contraction) and gross morphology. No morphometric software was used in this study.

\section{MATERIALS AND METHODS}

Overview of the experiment. To induce Acolpenteron ureteroecetes infections, juvenile largemouth bass were housed in a recirculating aquaculture system that shared water with tanks of infected sub-adult and adult largemouth bass. The juvenile bass were held in the infection system for up to $8 \mathrm{mo}$, for A. ureteroecetes prevalence to reach 75 to $80 \%$ (Gieseker et al. 2007). The parasites were collected from juvenile bass early in the infection cycle, since the initial infections yielded higher density infection than did the long-established infections.

After collection, Acolpenteron ureteroecetes were transferred to culture plates containing filtered tank water. Drugs of varying concentrations were added, and then the observations began. Control parasites did not receive any drug treatment, but received the appropriate diluents. In preliminary experiments, although control A. ureteroecetes lived for at least $48 \mathrm{~h}$, they were vigorous for only $30 \mathrm{~h}$; therefore experimental observations were ended after the first day.

Fish. Two batches of juvenile largemouth bass ( $\mathrm{n}=$ 200 each) were obtained from a commercial fish farm in New York state. Upon arrival at our laboratory, a subsample of 20 fish from Batch A measured $12.3 \pm$ $2.5 \mathrm{~cm}$ long (fork length; mean $\pm \mathrm{SD}$ ) and weighed $20.0 \pm 6.5 \mathrm{~g}, 2$ of these fish had very light Acolpenteron ureteroecetes infections; a subsample of 5 fish from Batch B measured $9.1 \pm 0.9 \mathrm{~cm}$ long and weighed $8.0 \pm$ $2.4 \mathrm{~g}$, no $A$. ureteroecetes infections were detected in these fish. Finding occasional $A$. ureteroecetes in the farmed fish was not unexpected, since the parasite is endemic in New York state.

The juvenile fish were given a pellet feed (Rangen) with $41 \%$ protein, at 3 to $5 \%$ body weight (BW) once daily, for $5 \mathrm{~d} \mathrm{wk}^{-1}$. The fish were acclimated in flow- 
through aquaria (60 l) for 2 mo prior to being moved into the infection system.

Infection system. A recirculating system consisting of 4 tanks was used to infect experimental fish. One tank contained previously infected sub-adults, and 2 tanks contained previously infected adults. Juvenile fish were added to the fourth tank, which shared water with the other tanks in the system. This system fostered continued infection with Acolpenteron ureteroecetes, by allowing parasites to spread via the water. The juvenile bass were held in the infection system for 3 to 8 mo prior to sacrifice for harvesting the parasites. In this time, prevalence reached 75 to $80 \%$, with moderate to heavy density (Gieseker et al. 2007). At harvest, the 117 juveniles were $16.4 \pm 2.3 \mathrm{~cm}$ long (fork length), and weighed $64.0 \pm 28.3 \mathrm{~g}$.

Infected carrier fish. The carrier bass consisted of 40 sub-adults and 23 adults infected during our previous study in which we characterized the time course of Acolpenteron ureteroecetes infection (Gieseker et al. 2007). Sub-adult fish were given the same feed as the juveniles, at 1 to $2 \% \mathrm{BW}$ once a day, $5 \mathrm{~d} \mathrm{wk}^{-1}$. Adult fish were fed extruded feed with $35 \%$ protein, at 0.5 to $1 \% \mathrm{BW}$ once a day, $3 \mathrm{~d} \mathrm{wk}^{-1}$.

Water quality. Temperature, dissolved oxygen, and $\mathrm{pH}$, were monitored continuously with electronic meters (Models 5300 and 9100, Royce Technologies), and maintained at $20.2 \pm 1.3^{\circ} \mathrm{C}$ (mean $\left.\pm \mathrm{SD}\right), 7.0 \pm$ $1.3 \mathrm{mg} \mathrm{l}^{-1}$, and $7.4 \pm 0.3$, respectively.

Antiparasitics. Seven antiparasitics were tested: 1 quinoline, praziquantel (Amtech); 1 imidazothiazide derivative, levamisole (Fluka-Sigma); 2 organophosphates, trichlorfon (Sigma) and dichlorvos (SpelcoSigma); 2 macrocyclic lactones, emamectin (Intervet/ Schering-Plough) and ivermection (Sigma); and 1 benzimidazole, mebendazole (Sigma). The concentrations of most of the drugs we used were based on doses recommended in the literature and in fish health formularies (Buchmann \& Bjerregaard 1990, Stoskopf 1993, Noga 1996, Kim \& Choi 1998, Hirazawa et al. 2000, Lewbart 2005).

Stock solutions of the drugs. Stock solutions of the drugs were prepared the day before testing, or on the day of testing, using sterile, ambient temperature, vacuum-filtered water $(0.2 \mu \mathrm{m}$ membrane filtration unit, Nalgene) from the infection system. The 3 waterinsoluble compounds, emamectin, ivermectin, and mebendazole, were first dissolved in $1 \mathrm{ml}$ of methanol or reagent alcohol, then diluted to the stock concentration with water. All subsequent dilutions of the stock solutions were made with filtered water. Serial dilutions were used to make a working solution of the drug at twice the final concentration needed for each dose level. Reagent blanks, for solvent effects, were tested in the bioassay.
Harvesting parasites. Juvenile fish were euthanatized by severing the cervical spine and double pithing. Using sterile technique, the posterior kidney was removed, and placed in $1 \mathrm{ml}$ of ambient-filtered tank water in a single well ( $6 \mathrm{ml}$ volume) of a 12-well culture plate. Teasing needles were flamed, and used to pull the kidney into small pieces without excess mincing, which can damage the parasites. The kidney fragments were left in the well plate for 1 to $2 \mathrm{~h}$ to allow parasites to migrate out of the tissue. Then sterilized forceps were used to remove the shredded tissue, and the remaining parasites were counted using an inverted microscope (Olympus IX70).

The parasites were transferred to another 12-well plate ( 3 parasites well ${ }^{-1}$ ) for the dosing trials, using a $10 \mu \mathrm{l}$ pipetor with $200 \mu \mathrm{l}$ tips. The $200 \mu \mathrm{l}$ tip orifice and $10 \mu \mathrm{l}$ volume were large enough to move the parasites without damage, while limiting the amount of debris transferred into the new well.

Bioassay. Three drug concentrations and one control were tested in triplicate, for all drugs except mebendazole for which a single dose and control were run in triplicate. The amount of filtered water needed to dilute the working solution $(1 \mathrm{ml})$ was first added to each well of a 12-well culture plate, then 3 parasites were placed in each well. After a 15 to 30 min acclimation, $1 \mathrm{ml}$ of the $2 \times$ drug solution was added to each well to achieve the final concentration.

Parasites were examined at 3 time periods: (1) $0 \mathrm{~h}$ immediately after adding the antiparasitic to the well (immediate), (2) 1-3 h (early), and (3) 17-26 h (late). In the control wells, at $17-26 \mathrm{~h}$, most parasites were alive, and of normal behavior and appearance, therefore this time period was a suitable cutoff for our observations.

At each time period, each parasite was scored as being normal (not affected), abnormal (affected) or dead. If abnormal, we noted the type of behavior and morphology according to specific criteria we adopted (Table 1). Death was defined as either a lack of movement or presence of obvious autolysis. Short videos were taken of the parasites to document normal movement, and the effect of the antiparasitics. The images were captured with StreamPix 3 digital video recording software (version 3.24.1, Norpix) using an inverted microscope fitted with a digital camera (Olympus 750).

\section{RESULTS \\ Overview}

The exposure effects criteria allowed us to document and quantify the effects of the 7 antiparasitics, and the different doses, at 3 time periods over a $26 \mathrm{~h}$ period. We used Time when either abnormal behavior or death 
Table 1. Exposure effect criteria for in vitro testing of anthelminthics against Acolpenteron ureteroecetes

\begin{tabular}{|ll|}
\hline $\begin{array}{l}\text { Response } \\
\text { Normal behavior }\end{array}$ & $\begin{array}{l}\text { Criteria } \\
\text { Normal movement: } \\
\text { Relaxation and contraction with twisting along } \\
\text { longitudinal axis } \\
\text { Twisting at the anterior and posterior ends of the } \\
\text { body } \\
\text { Hooklets moving in opisthaptor }\end{array}$ \\
$\begin{array}{l}\text { Adverse effects } \\
\text { Abnormal behavior }\end{array}$ & $\begin{array}{l}\text { (1) Reduced movement: } \\
\text { Reduced extent and/or speed of relaxation and }\end{array}$ \\
& contraction of body \\
& Reduced extent and/or speed of twisting at \\
& anterior and posterior ends \\
(2) Reduced movement of hooklets in opisthaptor \\
(3) Contracted \\
(1) Indentations or swellings \\
(2) Ringed constrictions \\
(3) Breaks in surface of body \\
(1) No movement \\
(2) Autolysis
\end{tabular}

Table 2. Overview of video captures of normal and abnormal behavior and morphology of Acolpenteron ureteroecetes during in vitro exposures to antiparasitics. Videos are available in the supplement at www.int-res.com/articles/ suppl/d094p059_supp/

\begin{tabular}{|llc|}
\hline Subject & Video ID & Duration (s) \\
\hline Control & CONT-1-attaching & \\
Adult & CONT-2-stretching-rotating & 0.08 \\
& CONT-3-rotating-sucker & 0.18 \\
& CONT-4-rotating-haptor & 0.03 \\
& CONT-5-haptor-hooklets & 0.09 \\
& CONT-6-egg-repro tract & 0.16 \\
Egg & CONT-7-egg-embryo & 0.23 \\
Larva & CONT-8-hatchling & 0.06 \\
Response: abnormal behavior & 0.31 \\
Slowed motion & RX-1-reduced motion-less stretching & 0.25 \\
Contracted & RX-2-reduced motion-ends bend & 0.09 \\
\multicolumn{1}{l}{ RX-3-contracted-minor body stretch } \\
Tremors & RX-4-contracted-minimal hooklet & 0.09 \\
Response: abnormal morphology & 0.06 \\
Segmental contractions & RX-6-reduced motion-segmented & 0.26 \\
\hline
\end{tabular}

\section{Bioassay}

No apparent effect

We assumed that normal parasite behavior and morphology indicated no response to the drug, that is to say, that the parasite was not susceptible to the drug. Normal behavior of the control monogeneans was documented using video microscopy (Table 1 and videos 'CONT-1 to CONT-8' listed in Table 2; all videos are available in the supplement at www.int-res.com/articles/ suppl/d094p059_supp/). Normal behavior consisted of moderate to vigorous activity, including attaching at anterior and posterior ends of the body, relaxation and contraction with twisting along the longitudinal axis of the body (Videos 'CONT-1-attaching' and 'CONT-2-stretching-rotating'), twisting at the ends of the body (Videos 'CONT-3-rotating-sucker' and 'CONT4-rotating-haptor'), and hooklets actively moving in the opisthaptor (Video 'CONT-5-haptor-hooklets') (Tables 1 \& 2).

Additional videos of the control parasites show the position of eggs within the parasite's uterus, motion of embryos within eggs, and swimming of the hatchlings (oncomiracidia) (Table 2; videos 'CONT-6-egg-repro tract', 'CONT-7-egg-embryo' and 'CONT-8-hatchling').

\section{Adverse effects on behavior,} morphology and survival

Abnormal behavior included reduced extent and speed of the normal relaxation, contraction, and twisting; and unusual movements namely contractions and tremors (Table 1, videos 'RX-1' to 'RX-5' in Table 2).

An additional manifestation of reswere observed, coupled with Number of parasites affected, to characterize the antiparasitic effectiveness. The susceptibility of Acolpenteron ureteroecetes to the 7 antihelminthics was summarized as (1) intense effect: praziquantel, levamisole, dichlorvos, trichlorfon; (2) moderate effect: emamectin, ivermectin; or (3) no observable effect: mebendazole. ponse was abnormal morphology, with indentations, swellings, ringed constrictions, and breaks in the surface of the body, or surface blebs (Tables $1 \& 2$, Video 'RX-6-reduced motion-segmented').

The parasite was assumed to be dead when there was no visible movement, and/or it was autolysed or had some other major physical damage (Table 1). 


\section{Response to the antiparasitics}

Controls

Most of the controls had normal behavior at all 3 time periods. A few control parasites (11 of 90) had slowed motion during the late observation periods. Deaths were very rare (6 of 90), and if seen, they usually occurred at the late time period. Control parasites never developed contracted morphology or tremors.

Some of the worms we used laid eggs in vitro during the observation period. In a few cases, the embryos could be seen moving within the eggs (Video 'CONT-7-egg-embryo') Some of the control eggs hatched after the $26 \mathrm{~h}$ point. The hatching oncomiracidia typically swam vigorously throughout the water column (Video 'CONT-8hatchling'). Since only few oncomiracidia were observed, no conclusions could be made regarding expected survival time.

\section{Treatments}

We observed that Acolpenteron ureteroecetes was immediately affected by some doses of praziquantel and levamisole in vitro (Table 3). When exposed to praziquantel at 5, 10, and 100 ppm, all parasites immediately showed abnormal behavior. The parasite's movements were slowed, they would contract to approximately half of their normal body length, and often developed full body tremors as they relaxed during the immediate and early observation periods (Video 'RX5-contracted-tremors-2-near dead'). At the late time period, parasites no longer contracted, but only moved the anterior and posterior (opisthaptor) ends (Video 'RX-2-reduced motionends bend'). When exposed to praziquantel at 500 and 1000 ppm, the parasites developed immediate tremors with moderate contraction, and all were dead at $1-3 \mathrm{~h}$.

Parasites exposed to levamisole had no observable response at the low con-
Table 3. Acolpenteron ureteroecetes. In vitro effects of 9 antiparasitics at 3 time periods. Nine parasites were tested for each treatment dose. The number of parasites affected at each time period are listed. If mortalities occurred, then the numbers are listed as no. of affected parasites/no. of remaining parasites. $\mathrm{AD}=$ all dead

\begin{tabular}{|c|c|c|c|c|c|c|c|}
\hline \multirow[t]{2}{*}{ Drug } & \multirow{2}{*}{$\begin{array}{l}\text { Conc. } \\
\text { (ppm) }\end{array}$} & \multicolumn{2}{|c|}{ Immediate (0 h) } & \multicolumn{2}{|c|}{ Early (1-3 h) } & \multicolumn{2}{|c|}{ Late (17-26 h) } \\
\hline & & $\begin{array}{l}\text { Abnormal } \\
\text { behavior }\end{array}$ & Dead & $\begin{array}{c}\text { Abnormal } \\
\text { behavior }\end{array}$ & Dead & $\begin{array}{c}\text { Abnormal } \\
\text { behavior }\end{array}$ & Dead \\
\hline \multicolumn{8}{|c|}{ Praziquantel } \\
\hline \multirow[t]{4}{*}{ Trial a } & 0 & 0 & 0 & 0 & 0 & 1 & 0 \\
\hline & 5 & 9 & 0 & 9 & 0 & $8 / 8$ & 1 \\
\hline & 10 & 9 & 0 & 9 & 0 & 9 & 0 \\
\hline & 100 & 9 & 0 & 9 & 0 & 9 & 0 \\
\hline \multirow[t]{4}{*}{ Trial b } & 0 & 0 & 0 & 0 & 0 & $1 / 8$ & 1 \\
\hline & 100 & 9 & 0 & 9 & 0 & $3 / 8^{a}$ & 1 \\
\hline & 500 & 9 & 0 & $\mathrm{AD}$ & $\mathrm{AD}$ & $\mathrm{AD}$ & $\mathrm{AD}$ \\
\hline & 1000 & 9 & 0 & $\mathrm{AD}$ & $\mathrm{AD}$ & $\mathrm{AD}$ & $\mathrm{AD}$ \\
\hline \multicolumn{8}{|c|}{ Levamisole } \\
\hline \multirow[t]{4}{*}{ Trial a } & 0 & 0 & 0 & 0 & 0 & 0 & 1 \\
\hline & 0.1 & 0 & 0 & 1 & 0 & 0 & 0 \\
\hline & 1 & 0 & 0 & 0 & 0 & 0 & 0 \\
\hline & 10 & 5 & 0 & 1 & 0 & 3 & 0 \\
\hline \multirow[t]{4}{*}{ Trial b } & 0 & 0 & 0 & 0 & 0 & $2 / 6$ & 3 \\
\hline & 10 & 9 & 0 & $4 / 7$ & 2 & $6 / 6$ & 3 \\
\hline & 50 & 9 & 0 & 7 & 0 & $4 / 4$ & 5 \\
\hline & 100 & 9 & 0 & 5 & 0 & $2 / 2$ & 7 \\
\hline \multicolumn{8}{|c|}{ Trichlorofon } \\
\hline & 0 & 0 & 0 & 0 & 0 & 0 & 0 \\
\hline & 0.25 & 0 & 0 & 3 & 0 & $2 / 2$ & 7 \\
\hline & 0.5 & 0 & 0 & 5 & 0 & $4 / 4$ & 5 \\
\hline & 1 & 0 & 0 & 9 & 0 & $2 / 2$ & 7 \\
\hline \multicolumn{8}{|c|}{ Dichlorovos } \\
\hline & 0 & 0 & 0 & 0 & 0 & 0 & 0 \\
\hline & 0.25 & 0 & 0 & $0^{\mathrm{b}}$ & $3^{\mathrm{b}}$ & $\mathrm{AD}$ & $\mathrm{AD}$ \\
\hline & 0.5 & 0 & 0 & 6 & 0 & $\mathrm{AD}$ & $\mathrm{AD}$ \\
\hline & 1 & 0 & 0 & $2 / 2$ & 7 & $\mathrm{AD}$ & $\mathrm{AD}$ \\
\hline \multicolumn{8}{|c|}{ Ivermectin } \\
\hline & 0 & 0 & 1 & $2 / 8$ & 1 & $4 / 8$ & 1 \\
\hline & 10 & 0 & 0 & 1 & 0 & $8 / 8$ & 1 \\
\hline & 50 & 0 & 0 & 1 & 0 & $4 / 4$ & 5 \\
\hline & 100 & 3 & 0 & $1 / 6$ & 3 & $2 / 2$ & 7 \\
\hline \multicolumn{8}{|c|}{ Emamectin } \\
\hline \multirow[t]{4}{*}{ Trial a } & 0 & 0 & 0 & 0 & 0 & 0 & 0 \\
\hline & 0.1 & 1 & 0 & 1 & 0 & 0 & 0 \\
\hline & 1 & 0 & 0 & 0 & 0 & 0 & 0 \\
\hline & 10 & 2 & 0 & 5 & 0 & $5 / 5$ & 4 \\
\hline \multirow[t]{4}{*}{ Trial b } & 0 & 0 & 0 & 0 & 0 & 0 & 0 \\
\hline & 10 & 0 & 0 & $1 / 1$ & 8 & $1 / 1$ & 8 \\
\hline & 50 & 1 & 0 & $2 / 2$ & 7 & $\mathrm{AD}$ & $\mathrm{AD}$ \\
\hline & 100 & 2 & 0 & $2 / 2$ & 7 & $\mathrm{AD}$ & $\mathrm{AD}$ \\
\hline \multicolumn{8}{|c|}{ Mebendazole } \\
\hline & 0 & 0 & 0 & 0 & 0 & 3 & 0 \\
\hline & 100 & 8 & 0 & 0 & 0 & 3 & 0 \\
\hline
\end{tabular}


centrations of 0.1 and $1.0 \mathrm{ppm}$. However, doses greater than $10 \mathrm{ppm}$ caused all parasites to immediately contract fully and stop moving $(0 \mathrm{~h})$. Some worms in the $10 \mathrm{ppm}$ dose group were less contracted and moving slowly again by $1-3 \mathrm{~h}$, compared to the worms exposed to 50 and $100 \mathrm{ppm}$ which were barely moving. By the late observation period, all the treatment dose worms were either moribund with minimal intermittent motion in the opisthaptor or dead.

The organophosphates, trichlorfon and dichlorvos, also caused significant morbidity and mortality at dosage ranges of 0.25 to $1.0 \mathrm{ppm}$. No immediate response was noted to trichlorfon or dichlorvos at any of the doses. During the early observation period, the response to trichlorfon was a dose-dependent reduction in motion, with less stretching (Videos 'RX-1reduced motion-less stretching' and 'RX-2-reduced motion-ends bend'). By the later observation period, some of the parasites were still alive, but their motion was severely impaired. These parasites had very contracted bodies, subtle body movement and occasional hooklet motion (Video 'RX-3-contracted-minor body stretch'). Some unusual peristaltic-like motion was observed with trichlorfon (Video 'RX-6-reduced motionsegmented').

Parasites treated with dichlorvos showed a dose response at the early time period, with the worms exposed to $1 \mathrm{ppm}$ extremely contracted with minimal motion (Video 'RX-4-contracted-minimal hook movement'). By the late time period, all worms were dead, and contracted.

Acolpenteron ureteroecetes was also affected by the avermectins, emamectin and ivermectin. Responses to these drugs were less intense than the responses to praziquantel, levamisole, and the organophosphates. Parasites exposed to emamectin had no apparent response at $0.1 \mathrm{ppm}$ and $1.0 \mathrm{ppm}$ doses. Some parasites exposed to 50 and $100 \mathrm{ppm}$ slowed immediately, and only slight movements were seen. By the end of the early observation period, most of the 10,50 and $100 \mathrm{ppm}$ parasites were dead, and the survivors had very limited movement. All emamectin treated parasites were dead by the late observation period.

There was generally no immediate response to ivermectin. A few of the parasites exposed to 100 ppm ivermectin were dead at the early time period, and all parasites exposed to ivermectin at 10,50, and $100 \mathrm{ppm}$ had little movement by the late time period, with over half dead in the 50 and $100 \mathrm{ppm}$ concentration.

Some of the Acolpenteron ureteroecetes exposed to 100 ppm mebendazole contracted initially and slowed their movement. However, these parasites had normal motion by the early observation period of $1-3 \mathrm{~h}$, and continued to move normally at the later observation period, $17-26 \mathrm{~h}$.

\section{DISCUSSION}

\section{In vitro tests for antiparasitics}

There are currently no drugs approved by USFDA to treat internal fish parasites and only 1 drug approved to treat external parasites. This is partially due to the fact that there are relatively few resources available for developing and testing drugs for minor and aquaculture species. One approach to reduce costs and numbers of experimental animals when evaluating potential drugs for use in fish is to conduct in vitro screens of approved terrestrial drugs against fish pathogens to find out which compounds are worthy of further study in vivo.

Evaluating the effectiveness of drugs to rid fish of parasites is a challenging task, especially if the parasites are internal. External parasites can be enumerated using non-lethal techniques such as skin smears and gill biopsies. Determining internal parasite load, however, usually requires sampling vital organs, thus sacrificing the fish. The study of the effects of a variety of different antiparasitics against internal parasites in vivo requires using an adequate number of fish to be certain that a high percentage of animals are infected. In addition, enough animals need to be tested to ensure that significant differences in parasite load can be demonstrated between treated and untreated fish. An in vitro study design can help reduce the number of experimental animals since the parasites can be obtained from relatively few fish. The in vitro study design allowed us to characterize changes in parasite behavior indicating a drug effect, the time course to abnormal behavior and time to parasite death. Such parameters would be very hard to determine in vivo.

In our study, Acolpenteron ureteroecetes survived in vitro with relatively normal activity up to about $30 \mathrm{~h}$, which provided adequate time to assess the effects of antiparasitics. Freshly collected A. ureteroecetes are very active, rapidly extending and contracting their bodies. Alterations of their normal movement provided a good marker of drug effect.

In vitro tests have previously been used to evaluate the resistance of parasites to various therapeutic agents. In vitro egg hatch assays have been used to measure resistance both experimentally (Martin et al. 1989) and as a field diagnostic aid (Le Jambre 1976, Ihler \& Bjørn 1996, Geerts \& Gryseels 2000). An in vitro larval development test (LDT) has been used to evaluate anthelmintic resistance in multiple mammalian species (Coles et al. 1988, Praslicka et al. 1997, Königová et al. 2003, Várady et al. 2006, 2009) and has been included in the guidelines of the World Association for the Advancement of Veterinary Parasitology (WAAVP) (Coles et al. 1992). 
Motility as an endpoint has been used to characterize effects of drugs on adult trematodes (Saowakon et al. 2009), nematodes (Bowen \& Vitayavirasak 2005, Buckingham \& Sattelle 2009, Ardelli et al. 2009) and copepods (Sevatdal et al. 2005, Westcott et al. 2008). Although sophisticated programs have been used to analyze helminth motility (Tsibidis \& Tavernarakis 2007, Restif \& Metaxas 2008, Tsechpenakis et al. 2008, Buckingham \& Sattelle 2009), such an approach may not be feasible for screening antihelminthics for aquaculture, due to limited resources. Basic observational techniques, such as those we used, can still provide valuable data on susceptibility of a parasite to a drug.

\section{Overview of drug effects}

We tested 7 different drugs, from 5 different classes, in our in vitro screen. The quinoline, imidazothiazide, and organophosphate compounds had the most deleterious effect on motility and survival. The macrocyclic lactones had a moderate effect, while the benzimidazole generally had no effect.

\section{Praziquantel}

Acolpenteron ureteroecetes was sensitive to praziquantel in our assay. We observed immediate contraction with slowed movement and whole body tremors at all of our doses (5 to 1000 ppm); mortality only occurred at the 500 and $1000 \mathrm{ppm}$. In previous studies on the use of praziquantel with fish parasites, the most commonly reported gross effects were on motility via contractions and/or tremors (Bylund et al. 1977, Hirazawa et al. 2000). In the monogenean Heterobothrium okamotoi, there was immediate contraction upon in vitro exposure to 20 ppm praziquantel, although tremors were not reported (Hirazawa et al. 2000). In plerocercoid cestode larvae from fish, Bylund et al. (1977) observed peristaltic muscle contractions at 10 to 300 ppm praziquantel, and mortality at the highest doses (600 to $700 \mathrm{ppm}$ ). Tegument damage (vacuolization) has only been observed with electron microscopy (Schmahl \& Mehlhorn 1985, Schmahl \& Taraschewski 1987).

Praziquantel, a pyrazinoisoquinoline drug, is widely used to treat parasitic infections in fish, animals and humans. For many species of bony and cartilaginous fish, praziquantel is used to treat monogenean and cestode infections (Bylund et al. 1977, Schmahl \& Mehlhorn 1985, Sanmartín Durán et al. 1989, Kim et al. 1998, Hirazawa et al. 2000, 2004, Kim \& Cho 2000, Chisholm \& Whittington 2002, Janse \& Borgsteede 2003, Onaka et al. 2003, Mitchell 2004, Sitjà-Bobadilla et al. 2006). In dogs, cats, horses, and ruminants, this drug is used to treat trematodes, cestodes, and nematodes (Johansen et al. 1996, Jenkins \& Romig 2000, Genchi et al. 2004, Ghazaei 2007, Grandemange et al. 2007, Slocombe et al. 2007), and in humans, praziquantel is a primary therapy for schistosomiasis (Tracy \& Webster 2001).

Praziquantel causes paralytic muscle contractions and tegument damage in parasites from fish and mammals, via an influx of calcium, which disrupts calcium homeostasis (Bylund et al. 1977, Schmahl \& Mehlhorn 1985, Schmahl \& Taraschewski 1987, Day et al. 1992, Redman et al. 1996, Hirazawa et al. 2000). However, the influx of calcium is not correlated with death of the worms in the case of schistosomes (Pica-Mattoccia et al. 2008).

\section{Levamisole}

In our study, Acolpenteron ureteroecetes contracted immediately upon contact with levamisole at doses of 10,50 , and $100 \mathrm{ppm}$; some parasites died within $3 \mathrm{~h}$, and all were dead by 17-26 h. Levamisole had a similar in vitro effect on 3 ectoparasitic monogeneans from fish: in Heterobothrium okamotoi, 20 ppm caused the parasite to contract and fall off gill arches (Hirazawa et al. 2000), in Diplozoon paradoxum, 10 to $50 \mathrm{ppm}$ reduced the movement and damaged the tegument (Schmahl \& Taraschewski 1987), and in Gyrodactylus aculeati, exposure to 10 to $50 \mathrm{ppm}$ reduced motility (Schmahl \& Taraschewski 1987).

Levamisole, a synthetic imidazothiazide, is used in fish and in a wide variety of animals to control parasitic nematodes (Thienpont et al. 1966, Jacobs 1987, Williams et al. 1991, Williams \& Broussard 1995). It has been investigated as a possible treatment for monogeneans (Schmahl \& Taraschewski 1987, Hirazawa et al. 2000) and is also used in pet aquarium medicine to treat nematodes (Harms 1996). Levamisole may be effective as a bath treatment but there is a rather small margin of safety. At 100 ppm, levamisole caused toxicity in sticklebacks Gasterosteus aculeatus (Schmahl \& Taraschewski 1987). Adult fish died after a 25 min bath exposure, but juvenile fish were able to recover. Although it is effective in vitro and in baths, levamisole administered in feed has not proven effective to control monogeneans (Hirazawa et al. 2000, Schalch et al. 2009).

Levamisole acts on nematode muscles by stimulating nicotinic acetylcholine receptors on the muscle membrane, causing prolonged membrane depolarization resulting in sustained muscle contractions (Harrow \& Gration 1985, Martin 1997). Levamisole (and related compounds pryantel and morantel) acts on the same 
ion channels as acetylcholine (Harrow \& Gration 1985, Pinnock et al. 1988, Levandoski et al. 2003).

\section{Organophosphates}

Although Acolpenteron ureteroecetes did not immediately respond to the organophosphates, a dose response was observed within $3 \mathrm{~h}$ at concentrations between 0.25 and $1 \mathrm{ppm}$. Affected parasites had slowed movement; at lower doses parasites were still able to move their entire bodies, but at higher doses the severely affected parasites were only moving their haptors. By 24 h, A. ureteroecetes was either severely impaired (only moving individual haptor hooklets) or dead at all doses. All of the parasites exposed to dichlorvos were dead by $24 \mathrm{~h}$, and most of those exposed to trichlorfon had also died.

Acolpenteron ureteroecetes was sensitive to both dichlorvos and trichlorfon at levels similar to those recommended ( 0.25 to $1 \mathrm{ppm}$ ) for prolonged immersion (Imada \& Muroga 1979, Noga 1996). Imada \& Muroga (1979) found that 0.5 to $1.0 \mathrm{ppm}$ trichlorfon (24 h) significantly decreased the prevalence of Pseudodactylogyrus microchis on eels Anguilla anguilla, although other researchers could not reproduce this effect (Buchmann et al. 1987). In addition, several Gyrodactylus species ( $G$. elegans, G. aculeati) have also been found to tolerate therapeutic levels of trichlorfon, either from intrinsic or developed tolerance (Goven et al. 1980, Schmahl \& Taraschewski 1987). An in vitro exposure to trichlorfon (Neguvon®) or dichlorvos (Nuvan®) affected cholinesterase activity in Pseudodactylogyrus anguillae. Trichlorfon did not immobilize the parasites completely at 100 ppm, but dichlorvos did at concentrations as low as 1.5 ppm (Buchmann \& Mellergaard 1988). In the present study, A. ureteroecetes was sensitive to much lower dosages of organophosphates ( 0.25 to $1 \mathrm{ppm}$ ) compared with the higher dosages of praziquantel and levamasole (10 to $100 \mathrm{ppm})$. However, the toxicity of the drug to the host must be considered when evaluating the response of parasites to drugs in vitro and in vivo. For example, eels developed spasms when exposed to $5 \mathrm{ppm}$ trichlorfon, suggesting a tolerance limit (Buchman et al. 1987).

Both trichlorfon and dichlorvos have been recommended for treating external monogenean infections in fish (Stoskopf 1993, Noga 1996), but researchers have found varied sensitivity to these drugs (Imada \& Muroga 1979, Goven et al. 1980, Schmahl \& Taraschewski 1987, Buchmann et al. 1987). Both drugs have also been used to control sea lice on salmon farms (Brandal \& Egidius 1979), and to eradicate anchor worm Lernaea sp. larvae (Noga 1996, Tonguthai 1997).
In addition, trichlorfon and dichlorvos are used in a variety of animals to control parasitic nematodes. Dichlorvos is also used in swine and dogs for intestinal and lung nematodes (Robinson 1979), and both of these organophosphates are used in horses against strongyle nematodes and bot fly larvae (Drudge et al. 1984).

Organophosphates inhibit acetylcholinesterase thereby blocking degradation of the neurotransmitter, acetylcholine, disrupting motor neurons (Martin 1997). The mode of action is not specific and therefore can have toxic effects to the host and other non-target organisms (Egidius \& Møster 1987, Le Bris et al. 1995).

\section{Avermectins}

In our study, ivermectin and emamectin caused abnormal behavior at 10,50 and $100 \mathrm{ppm}$ in the first hour. Activity was slowed, and the worms did not relax to a fully extended length, but remaining approximately half of their fully extended length, and movement was restricted to only the prohaptor and haptor regions. Worms exposed to 50 or 100 ppm were severely compromised or dead by the late time period.

Similar results have been found in other parasites. The copepod, Lepeophtheirus salmonis, exhibited uncoordinated movement and inability to attach to the substrate when exposed to emamectin in vitro (Westcott et al. 2008). Two main morphologic or behavioral effects have been observed when avermectins are applied to nematodes in vitro: (1) inhibited pharyngeal pumping, followed by a generalized, rapid paralysis (Geary et al. 1993, Gill et al. 1995, Keane \& Avery 2003). Once the parasites are unable to move or feed, they are eliminated from the host (Geary et al. 1993, Gill \& Lacey 1998). Mid-body paralysis following administration of ivermectin to adult Haemonchus contortus nematodes in vitro was reported by Geary et al. (1993). Reduction in ingestion or pharyngeal pumping, however, occurred at a much lower dose than that which inhibited motility. Gill et al. (1995) exposed $H$. contortus larvae to high and low doses of ivermectin. High doses of ivermectin caused jerky angular motions in larvae soon after exposure. Larvae exposed to low doses had normal activity for up to $36 \mathrm{~h}$ of exposure, when motility became sluggish. Development to the next stage, however, was inhibited at the low dose of ivermectin even if motility was normal. Rapson et al. (1985) also found larval development was affected at a much lower dose than that affecting motility in Trichostrongylus columbriformis. In contrast, Ardelli et al. (2009) noted that, in vitro, the non-parasitic nematode Caenorhabditis elegans exhibited a period of hyperactivity between 1 and $2 \mathrm{~h}$ after treatment with $2.5 \mathrm{nM}$ 
or $5 \mathrm{nM}$, but not $10 \mathrm{nM}(4.3,8.5$, and $17 \mathrm{ppb}$, respectively) ivermectin. After $2.5 \mathrm{~h}$, however, $67 \%$ of worms stop all activity.

Avermectins are currently used in fish medicine. Emamectin benzoate is a semi-synthetic avermectin approved by the EU and Canada to control sea louse Lepeophtheirus salmonis affecting salmonids (EMEA 2003, Lees et al. 2008; see also Health Canada - www. hc.sc.gc/dhp-mps/consultation/vet/consultations/pastanterieures/residu/2009-mrl-lmr-vdd-dmv/lett-eng.php). Emamectin has also been shown effective against another fish ectoparasite, the lernaeapodid copepod Salmincola californiensis (Roberts et al. 2004), and may be useful for Lernanthropus kroyeri infections of sea bass (Athanassopoulou et al. 2009).

Avermectins are effective against a variety of parasites in domestic animals and humans (Lasota \& Dybas 1991). Ivermectin is widely used in veterinary medicine against heart worms (Dirofilaria immitis) in dogs and cats (Bowen \& Vitayavirasak 2005), and is also used to treat many internal and external parasites of cattle, pigs, horses, (Williams \& Plue 1992, Geurden et al. 2003, Santarém et al. 2005, López-Olvera et al. 2006, Lyndal-Murphy et al. 2010), and even ostriches (Geurden et al. 2009).

Avermectins are macrocyclic lactones which increase the membrane permeability of invertebrate nerves and muscles to the chloride anion $\left(\mathrm{Cl}^{-}\right)$(Fritz el al. 1979, Martin 1997). The action appears to be on a glutamate-gated $\mathrm{Cl}^{-}$channel (Cully et al. 1994, Ardelli et al. 2009), which is composed of several subunits (Wolstenholme \& Rogers 2005, McCavera et al. 2009). This mechanism is well documented in adult parasites, but the affect on microfilaria has not been elucidated as they appear unaffected in vitro, yet disappear rapidly from the blood or skin of treated animals (Geary et al. 2010).

\section{Benzimidazoles}

In our study, Acolpenteron ureteroecetes was generally not susceptible to mebendazole. Although this drug caused some contraction immediately after administration, the parasites returned to normal activity within the first hour. We also noted this lack of responsiveness in a preliminary evaluation of the benzimidazoles albendazole and ricobendazole (data not shown). Those drugs were tested at much lower dosages, 0.025 to $1.0 \mathrm{ppm}$, based on residue levels of albendazole and its metabolites found in fish tissues (Shaikh et al. 2007). No adverse response was observed to either of these benzimidazoles at those doses. Based on our in vitro findings with mebendazole at the higher dose, we expect benzimidazoles to be relatively ineffective in vivo. However, benzimidazole in vitro responses do not always reflect in vivo responses (Santamarina et al. 1991, Tojo et al. 1992). There may be effects on reproduction of the parasite that are not identified in vitro, which could explain the clinical response seen in some studies.

In fish, benzimidazoles have been tested primarily against the platyhelminths. For example, bath treatment with mebendazole was effective on the gill monogenean Gyrodactylus elegans but not on Dactylogyrus vastator (Goven \& Amend 1982). Mebendazole was ineffective treating Microcotyle sp. in red porgy Pagrus pagrus (Katharios et al. 2006), but showed some efficacy on Gyrodactylus sp. of trout Oncorhynchus mykiss (Tojo et al. 1992) with prolonged (12 h) but not short bath treatments (1 to $3 \mathrm{~h}$ ). Benzimidazoles have also been tested against protozoan, microsporidian, and nematode parasites of fish. Triclabendazole caused reduction in the infection degree and trophont size of the ciliate Ichthyophthiriosis sp. in rainbow trout when administered orally (Rodriguez \& Fernandez 2001, Luzardo-Álvareza et al. 2003). Several benzimidazoles markedly reduce spore infectivity in the microsporidian Glugea anomala of sticklebacks Gasterosteus aculeatus (Schmahl \& Benini 1998). Mebendazole and other benzimidazoles were ineffective against Anguillicola crassus, the air bladder nematode of eels (Taraschewski et al. 1988).

In the case of external parasites, in vitro testing might be considered to be very similar to in vivo treatment since the parasite is exposed to the drug primarily via a surface route (bath). An in vivo response, however, does not always correspond to in vitro results. For example, in eels, Pseudodactylogyrus spp. responded to in vivo treatment with mebendazole (Szekely \& Molnar 1987, Mellergaard 1990, Buchmann 1993), however in vitro experiments showed different drug-susceptibility of $P$. bini and $P$. anguillae (Buchmann \& Bjerregaard 1990). Some inhibition of parasite egg development was also observed in vitro. Similarly, different responses were noted between in vivo and in vitro results for benzimidazoles tested on Gyrodactylus sp. from trout (Tojo et al. 1992, Tojo \& Santamarina 1998).

Benzimidazoles have a broad spectrum of activity against various parasites (Sharma \& Abuzar 1983, McKellar \& Scott 1990, Williams \& Broussard 1995). Used throughout the world against gastro-intestinal and respiratory nematodes of livestock, some benzimidazoles are also effective against trematodes and cestodes (Schmidt 1998, Robinson et al. 2002, Keiser et al. 2005). Benzimidazoles are also used to treat parasites of companion animals, including protozoan infections such as Giardia sp. (Barr et al. 1993, Xiao et al. 1996) and nematodes such as Toxocara species (Parsons 
1987, Fisher et al. 1993). Microsporidial infections in domestic animals and humans have also been treated using this class of drugs (Dore et al. 1995, Didier et al. 2005).

Although the mechanisms of action of these heterocyclic compounds are not fully understood, benzimidazoles bind the $\beta$-tubulin molecule, similar to the 'capping' process of colchicine and vincristine (McKellar \& Scott 1990, Lubega \& Prichard 1991a,b, Martin 1997), thereby disrupting cell functions such as cell division and transport. Subsequent effects on the rate and turnover of cellular process are thought to inhibit egg hatching (Lacey et al. 1987). Furthermore, interference with apical secretory vesicle transport causes release of digestive enzymes into the intestinal wall of nematodes such as Haemonchus contortus (Shompole et al. 2002). In cestodes, the disruption of microtubule formation reduces glucose uptake, followed by reduced glycogen content and tegument surface lesions (Schmidt 1998, Cumino et al. 2009).

The importance of tubulin binding by benzimidazoles has been demonstrated by the finding that parasites that are resistant to these drugs have mutations in the $\beta$-tubulin gene (Kwa et al. 1995, Höglund et al. 2009, Lake et al. 2009, Rufener et al. 2009). In vitro studies of benzimidazole resistance have used a tubulin-binding assay as well as egg hatch assays (Johansen \& Waller 1989, Martin et al. 1989).

\section{Critique of our study}

Our study, using 3 concentrations and one control per drug, and 3 time periods, allowed us to screen 7 antiparasitics, and determine the susceptibility of Acolpenteron ureteroecetes to them. By using a combination of criteria (abnormal behavior and death) at the different time periods, we divided the effects of the drugs on the parasites into 3 categories: large effect, moderate effect, and no observable effect.

Future refinements to similar studies could include more time points and more parasites to obtain a dataset large enough for statistical analysis. The exact number of parasites per concentration per time point would depend on the variability of the response to treatment to different parasiticides. This could be determined with preliminary studies. We also recommend an additional time point in between the 1-3 $\mathrm{h}$ and the 17-26 h time periods, with a consistent narrow time window for each time point, for example $2 \mathrm{~h}$, for a more definitive study.

We suggest that some of the variation in our dataset may have reflected differences in the ages of the worms. This phenomenon has been documented in previous trails of the effects of praziquantel on schisto- somes, in which exposure causes immediate contraction, but death depends on the maturity (and sex) of the worms (Pica-Mattoccia \& Cioli 2004).

\section{CONCLUSION}

This is the first report of avermectin parasiticides having an effect on a monogenean parasite. The responsiveness to emamectin may develop into an additional use for this drug in aquatic species, since it is widely used in salmonids to treat sea lice. Acolpenteron ureteroecetes was also sensitive to praziquantel, levamisole, dichlorvos, and trichlorfon at dose levels similar to those seen in other monogeneans that have no intrinsic or developed tolerance. These drugs, therefore, are potential candidates to test in vivo. The potential dosages used in vivo, however, would depend on several factors such as route of administration, absorption, and the ability of drug to get to the site of infection at an effective concentration.

In addition to evaluating potential treatments for Acolpenteron ureteroecetes, this study provides an example of how observations can be systematically used to screen for drug effects in vitro. Such an approach can evaluate subtle changes that cannot be observed in vivo, particularly for internal parasites. Motility is an important parameter to include in the analysis because parasites must migrate on or within the host, or between hosts to continue their life cycle. Activity, along with other physiological or reproductive parameters, is commonly used to determine potentially successful parasiticide candidates, or to monitor the development of resistance to treatments. A clearly defined set of observational characteristics can help reduce inter-observer error (Westcott et al. 2008). Capturing video images of normal and abnormal motility can also help reduce such errors, since the videos can be used both to train observers, and to record findings so that multiple observers can evaluate the same results. Videos can also be used to document unusual responses. Documenting such findings can help define a wider range of responses that may be observed less frequently, and thus may have been under-reported in past studies.

Some researchers studying parasites of major public health concern such as schistosomes have used elaborate video and computer measurement systems to analyze the effect drugs have on parasite activity. Because such systems may not be readily available to fish researchers, a more classic, observational approach with simple video capture to document findings, as used in this study, can be useful for generating data on the response of parasites to candidate drugs 
Acknowledgements. We thank C.-S. Cheely and N. Hasbrouck for assisting in harvesting parasites and conducting the bioassays.

\section{LITERATURE CITED}

Ardelli BF, Stitt LE, Tompkins JB, Prichard RK (2009) A comparison of the effects of ivermectin and moxidectin on the nematode Caenorhabditis elegans. Vet Parasitol 165: 96-108

Athanassopoulou F, Pappas IS, Bitchava K (2009) An overview of the treatments for parasitic disease in Mediterranean aquaculture on development of Gulgea anomala, Moniez, 1887 (Microsporidia). Options Méditerran 86: 65-83

> Barr SC, Bowman DD, Heller RL, Erb HN (1993) Efficacy of albendazole against giardiasis in dogs. Am J Vet Res 54: 926-928

Bowen JM, Vitayavirasak B (2005) Contractile activity and motility responses of the dog heartworm Dirofilaria immitis to classical anthelmintics and other compounds. Vet Parasitol 134:183-188

Brandal PO, Egidius E (1979) Treatment of salmon lice (Lepeoptheirus salmonis Krǿyer, 1838) with Neguvon ${ }^{\circ}-$ description of method and equipment. Aquaculture 18: 183-188

Buchmann K (1993) Epidemiology and control of Pseudodactylogyrus infections in intensive eel culture systems: recent trends. Bull Fr Peche Piscicult 328:66-73

Buchmann K, Bjerregaard J (1990) Mebendazole treatment of pseudodactylogyrosis in an intensive eel-culture system. Aquaculture 86:139-153

Buchmann K, Mellergaard S (1988) Histochemical demonstration of the inhibitory effect of Nuvan ${ }^{\circledR}$ and Neguvon ${ }^{\circledR}$ on cholinesterase activity in Psuedodactylogyrus anquillae (Monogenea). Acta Vet Scand 29:51-55

Buchmann K, Mellergaard S, Køie M (1987) Pseudodactylogyrus infections in eel: a review. Dis Aquat Org 3:51-57

> Buckingham SD, Sattelle DB (2009) Fast, automated measurement of nematode swimming (thrashing) without morphometry. BMC Neurosci 10:84-90

Bylund G, Bång B, Wikgren K (1977) Tests with a new compound (Praziquantel) against Diphyllobothrium latum. J Helminthol 51:115-119

> Chisholm LA, Whittington ID (2002) Efficacy of praziquantel bath treatments of monogenean infections of the Rhinobatos typus. J Aquat Anim Health 14:230-234

> Coles GC, Tritschler JP II, Giordano DJ, Laste NJ, Schmidt AL (1988) Larval development test for detection of anthelmintic resistant nematodes. Res Vet Sci 45:50-53

Coles GC, Bauer C, Borgsteede FHM, Geerts S, Klei TR, Taylor MA, Waller PJ (1992) World Association for the Advancement of Veterinary Parasitology (W.A.A.V.P.) methods for the detection of anthelmintic resistance in nematodes of veterinary importance. Vet Parasitol 44: 35-44

> Cully DF, Vassilatis DK, Liu KK, Paress PS, Van der Ploeg LH, Schaeffer JM, Arena JP (1994) Cloning of an avermectinsensitive glutamate-gated chloride channel from Caenorhabditis elegans. Nature 371:707-711

Cumino AC, Elissondo MC, Denegri GM (2009) Flubendazole interferes with a wide spectrum of cell homeostatic mechanisms in Echinococcus granulosus protoscoleces. Parasitol Int 58:270-277

> Day TA, Bennett JL, Pax RA (1992) Praziquantel: the enigmatic antiparasitic. Parasitol Today 8:342-344

Didier ES, Maddry JA, Brindley PJ, Stovall ME, Didier PJ
(2005) Therapeutic strategies for human microsporidia infections. Expert Rev Anti Infect Ther 3:419-434

Dore GJ, Marriott DJ, Hing MC, Harkness JL, Field AS (1995) Disseminated microsporidiosis due to Septata intestinalis in nine patients infected with the human immunodeficiency virus: response to therapy with albendazole. Clin Infect Dis 21:70-76

Drudge JH, Lyons ET, Tolliver SC (1984) Critical tests of morantel-trichlorfon paste formulation against internal parasites of the horse. Vet Parasitol 14:55-64

Du Plessis SS (1948) A gyrodactyloid parasite from the ureters of largemouth bass at the Jonkershoek Inland Fish Hatchery, South Africa. Trans Am Fish Soc 75:105-109

> Egidius E, Møster B (1987) Effect of Neguvon ${ }^{\circledR}$ and Nuvan® treatment on crabs (Cancer pagurus, C. maenas), lobster (Homarus gammarus) and blue mussel (Mytilus edulis). Aquaculture 60:165-168

EMEA (European Medicines Agency) (2003) Committee for Veterinary Medicinal Products. Summary report: emamectin (1). Report no. EMEA/MRL/546/99-FINAL. EMEA, London. Available at www.emea.europa.eu/pdfs/ vet/mrls/086303en.pdf

> Fischthal JH, Allison LN (1941) Acolpenteron ureteroecetes Fischthal and Allison, 1940, a monogenetic trematode from the ureters of the black basses, with a revision of the family Calceostomatidae (Gyrodactyloidea). J Parasitol 27: $517-524$

Fisher MA, Jacobs DE, Hutchinson MJ, Abbott EM (1993) Efficacy of fenbendazole and piperazine against developing stages of Toxocara and Toxascaris in dogs. Vet Rec 132:473-475

> Fritz LC, Wang CC, Gorio A (1979) Avermectin B1a irreversibly blocks postsynaptic potentials at the lobster neuromuscular junction by reducing muscle membrane resistance. Proc Natl Acad Sci USA 76:2062-2066

> Geary TG, Sims SM, Thomas EM, Vanover L and others (1993) Haemonchus contortus: ivermectin-induced paralysis of the pharynx. Exp Parasitol 77:88-96

- Geary TG, Woo K, McCarthy JS, Mackenzie CD and others (2010) Unresolved issues in anthelmintic pharmacology for helminthiases of humans. Int J Parasitol 40:1-13

Geerts S, Gryseels B (2000) Drug resistance in human helminths: current situation and lessons from livestock. Clin Microbiol Rev 13:207-222

Genchi C, Cody R, Pengo G, Büscher G, Cavalleri D, Bucci V, Junquera P (2004) Efficacy of a single milbemycin oxime administration in combination with praziquantel against experimentally induced heartworm (Dirofilaria immitis) infection in cats. Vet Parasitol 122:287-292

Geurden T, Verelst A, Somers R, Dierickx N, Vercruysse J (2003) Efficacy of ivermectin against Sarcoptes scabiei var suis in pigs. Vet Rec 153:272-273

Geurden T, van Leuven M, Meeus P, Vercruysse J, Claerebout E (2009) Trichostrongylid nematode infections in ostriches (Struthio camelus) in Belgium. Vet Rec 164: $181-182$

Ghazaei C (2007) Evaluation therapeutic effects of antihelminthic agents albendazole, fenbendazole and praziquantel against coenurosis in sheep. Small Rumin Res 71: 48-51

> Gieseker CM, Serfling SG, Poynton SL, Reimschuessel R (2007) Laboratory transmission of the monogenean Acolpenteron ureteroecetes infecting the posterior kidneys of largemouth bass: time course and pathology. J Aquat Anim Health 19:141-150

Gill JH, Lacey E (1998) Avermectin/milbemycin resistance in trichostrongyloid nematodes. Int J Parasitol 28:863-877 
Gill JH, Redwin JM, van Wyk JA, Lacey E (1995) Avermectin inhibition of larval development in Haemonchus contortus-effects of ivermectin resistance. Int J Parasitol 25: 463-470

Goven BA, Amend DF (1982) Mebendazole/trichlorfon combination: a new anthelmintic for removing monogenetic trematodes from fish. J Fish Biol 20:373-378

Goven BA, Gilbert JP, Gratzek JB (1980) Apparent drug resistance to the organophosphate dimethyl $(2,2,2$-trichloro-1hydroxyethyl) phosphonate by monogenetic trematodes. J Wildl Dis 16:343-346

Grandemange E, Claerebout E, Genchi C, Franc M (2007) Field evaluation of the efficacy and the safety of a combination of oxantel/pyrantel/praziquantel in the treatment of naturally acquired gastrointestinal nematode and/or cestode infestations in dogs in Europe. Vet Parasitol 145: 94-99

Harms CA (1996) Treatments for parasitic diseases of aquarium and ornamental fish. Semin Avian Exot Pet Med 5: $54-63$

- Harrow ID, Gration KAF (1985) Mode of action of the anthelmintics morantel, pyrantel and levamisole on muscle cell membrane of the nematode Ascaris suum. Pestic Sci 16:662-672

> Hirazawa N, Ohtaka T, Hata K (2000) Challenge trials on the anthelmintic effect of drugs and natural agents against the monogenean Heterobothrium okamotoi in the tiger puffer Takifugu rubripes. Aquaculture 188:1-13

- Hirazawa N, Mitsuboshi T, Hirate T, Shirasu K (2004) Susceptibility of spotted halibut Verasper variegatus (Pleuronectidae) to infection by the monogenean Neobenedenia girellae (Capsalidae) and oral therapy trials using praziquantel. Aquaculture 238:83-95

Höglund J, Gustafsson K, Ljungström BL, Engström A, Donnan A, Skuce P (2009) Anthelmintic resistance in Swedish sheep flocks based on a comparison of the results from the faecal egg count reduction test and resistant allele frequencies of the beta-tubulin gene. Vet Parasitol 161:60-68

> Ihler CF, Bjørn H (1996) Use of two in vitro methods for the detection of benzimidazole resistance in equine small strongyles (Cyathostoma spp.). Vet Parasitol 65:117-125

Imada R, Muroga K (1979) Pseudodactylogyrus microrchis (Monogenea) on the gills of cultured eels. III. Experimental control by trichlorfon. Bull Jpn Soc Sci Fish 45:25-29

Jacobs DE (1987) Anthelmintic for dog and cats. Int J Parasitol 17:511-518

Janse M, Borgsteede HM (2003) Praziquantel treatment of captive white-spotted eagle rays (Aetobatus narinari) infested with monogean trematodes. Bull Eur Assoc Fish Pathol 23:152-156

Jenkins DJ, Romig T (2000) Efficacy of Droncit ${ }^{\circledR}$ Spot-on (praziquantel) $4 \% \mathrm{w} / \mathrm{v}$ against immature and mature Echinococcus multilocularis in cats. Int $\mathrm{J}$ Parasitol 30: 959-962

> Johansen MV, Monrad J, Christensen NØ (1996) Effects of praziquantel on experimental Schistosoma bovis infection in goats. Vet Parasitol 62:83-91

Johansen MV, Waller PJ (1989) Comparison of three in vitro techniques to estimate benzimidazole resistance in Haemonchus contortus of sheep. Vet Parasitol 34:213-221

Katharios P, Papandroulakis N, Divanach P (2006) Treatment of Microcotyle sp. (Monogenea) on the gills of cagecultured red porgy, Pagrus pagrus following baths with formalin and mebendazole. Aquaculture 251:167-171

Keane J, Avery L (2003) Mechanosensory inputs influence Caenorhabditis elegans pharyngeal activity via ivermectin sensitivity genes. Genetics 164:153-162
Keiser J, Engels D, Büscher G, Utzinger J (2005) Triclabendazole for the treatment of fascioliasis and paragonimiasis. Expert Opin Investig Drugs 14:1513-1526

> Kim KH, Cho JB (2000) Treatment of Microcotyle sebastis (Monogenea: Polyopisthocotylea) infestation with praziquantel in an experimental cage simulating commercial rockfish Sebastes schlegeli culture conditions. Dis Aquat Org 40:229-231

Kim KH, Choi ES (1998) Treatment of Microcotyle sebastis (Monogenea) on the gills of cultured rockfish (Sebastes schelegeli) with oral administration of mebendazole and bithionol. Aquaculture 167:115-121

Kim KH, Park SI, Jee BY (1998) Efficacy of oral administration of praziquantel and mebendazole against Microcotyle sebastis (Monogenea) infestation of cultured rockfish (Sebastes schlegeli). Fish Pathol 33:467-471

Königová A, Várady M, Corba J (2003) Comparison of in vitro methods and faecal egg count reduction test for the detection of benzimidazole resistance in small strongyles of horses. Vet Res Commun 27:281-288

Kwa MSG, Veenstra JG, Van Dijk M, Roos MH (1995) Betatubulin genes from the parasitic nematode Haemonchus contortus modulate drug resistance in Caenorhabditis elegans. J Mol Biol 246:500-510

> Lacey E, Brady RL, Prichard RK, Watson TR (1987) Comparison of inhibition of polymerisation of mammalian tubulin and helminth ovicidal activity by benzimidazole carbamates. Vet Parasitol 23:105-119

> Lake SL, Matthews JB, Kaplan RM, Hodgkinson JE (2009) Determination of genomic DNA sequences for beta-tubulin isotype 1 from multiple species of cyathostomin and detection of resistance alleles in third-stage larvae from horses with naturally acquired infections. Parasites Vectors 2(Suppl 2):S6

Lasota JA, Dybas RA (1991) Avermectins, a novel class of compounds: implications for use in arthropod pest control. Annu Rev Entomol 36:91-117

> Le Bris H, Maffart P, Bocquené G, Buchet V, Galgani F, Blanc G (1995) Laboratory study on the effect of dichlorvos on two commercial bivalves. Aquaculture 138:139-144

> Le Jambre LF (1976) Egg hatch as an in-vitro assay of thiabendazole resistance in nematodes. Vet Parasitol 2: 385-391

Lees F, Gettinby G, Revie CW (2008) Changes in epidemiological patterns of sea lice infestation on farmed Atlantic salmon, Salmo salar L., in Scotland between 1996 and 2006. J Fish Dis 31:259-268

- Levandoski MM, Piket B, Chang J (2003) The anthelmintic levamisole is an allosteric modulator of human neuronal nicotinic acetylcholine receptors. Eur J Pharmacol 471: 9-20

Lewbart GA (2005) Formulary and biologic/medical information: fish. In: Carpenter JW (ed) Exotic animal formulary. Elsevier Saunders, Saint Louis, MO, p 5-29

López-Olvera JR, Höfle U, Vicente J, Fernández-de-Mera IG, Gortázar C (2006) Effects of parasitic helminths and ivermectin treatment on clinical parameters in the European wild boar (Sus scrofa). Parasitol Res 98:582-587

Lubega GW, Prichard RK (1991a) Interaction of benzimidazole anthelmintics with Haemonchus contortus tubulin: binding affinity and anthelmintic efficacy. Exp Parasitol 73:203-213 $p<$

Lubega GW, Prichard RK (1991b) Specific interaction of benzimidazole anthelmintics with tubulin from developing stages of thiabendazole-susceptible and -resistant Haemonchus contortus. Biochem Pharmacol 41:93-101

Luzardo-Álvarez A, Martínez-Mazagatos J, Santamarina-Fer- 
nández MT, Otero-Espinar FJ, Blanco-Méndez J (2003) Oral pharmacological treatments for Ichthyophthiriosis of rainbow trout (Oncorhynchus mykiss). Aquaculture 220: $15-25$

Lyndal-Murphy M, Rogers D, Ehrlich WK, James PJ, Pepper PM (2010) Reduced efficacy of macrocyclic lactone treatments in controlling gastrointestinal nematode infections of weaner dairy calves in subtropical eastern Australia. Vet Parasitol 168:146-150

Martin RJ (1997) Modes of action of anthelmintic drugs. Vet J 154:11-34

Martin PJ, Anderson N, Jarret RG (1989) Detecting benzimidazole resistance with faecal egg count reduction tests and in vitro assays. Aust Vet J 66:236-240

McCavera S, Rogers AT, Yates DM, Woods DJ, Wolstenholme AJ (2009) An ivermectin-sensitive glutamate-gated chloride channel from the parasitic nematode Haemonchus contortus. Mol Pharmacol 75:1347-1355

McKellar QA, Scott EW (1990) The benzimidazole anthelmintic agents - a review. J Vet Pharmacol Ther 13: 223-247

Mellergaard S (1990) Mebendazole treatment against Pseudodactylogyrus infections in eel (Anguilla anguilla). Aquaculture 91:15-21

> Mitchell A (2004) Effectiveness of praziquantel bath treatments against Bothriocephalus acheilognathi in grass carp. J Aquat Anim Health 16:130-136

Noga EJ (1996) Fish disease: diagnosis and treatment. Mosby, Saint Louis, MO

Onaka EM, Martins ML, Moraes FR (2003) Albendazole and praziquantel efficacy against Anacanthorus penilabiatus (Monogenea: Dactylogyridae), gill parasite of Piaractus mesopotamicus (Osteichthyes: Characidae). I. Therapeutic baths. Bol Inst Pesca São Paulo 29:101-107

Parsons JC (1987) Ascarid infections of cats and dogs. Vet Clin North Am Small Anim Pract 17:1307-1339

> Petrie-Hanson L (2001) First reported mortality and associated pathology attributed to Acolpenteron ureteroecetes in largemouth bass. J Aquat Anim Health 13:364-367

Pica-Mattoccia L, Cioli D (2004) Sex- and stage-related sensitivity of Schistosoma mansoni to in vivo and in vitro praziquantel treatment. Int J Parasitol 34:527-533

Pica-Mattoccia L, Orsini T, Basso A, Festucci A and others (2008) Schistosoma mansoni: Lack of correlation between praziquantel-induced intra-worm calcium influx and parasite death. Exp Parasitol 119:332-335

Pinnock RD, Sattelle DB, Gration KAF, Harrow ID (1988) Actions of potent cholinergic anthelmintics (morantel, pyrantel and levamisole) on an identified insect neurone reveal pharmacological differences between nematode and insect acetylcholine receptors. Neuropharmacology 27:843-848

> Praslicka J, Bjørn H, Várady M, Nansen P, Hennessy DR, Talvik H (1997) An in vivo dose-response study of fenbendazole against Oesophagostomum dentatum and Oesophagostomum quadrispinulatum in pigs. Int J Parasitol 27:403-409

Rapson EB, Jenkins DC, Topley P (1985) Trichostrongylus colubriformis: in vitro culture of parasitic stages and their use for the evaluation of anthelmintics. Res Vet Sci 39:90-94

Redman CA, Robertson A, Fallon PG, Modha J, Kusel JR, Doenhoff MJ, Martin RJ (1996) Praziquantel: an urgent and exciting challenge. Parasitol Today 12:14-20

Restif C, Metaxas D (2008) Tracking the swimming motions of C. elegans worms with applications in aging studies. In: Metaxas D, Axel L, Fichtinger G, Székely G (eds) Medical image computing and computer assisted interventions -
MICCAI 2008. 11th Int Conf, New York, 6-10 Sep, Proc Part I. Springer-Verlag, New York, NY, p 35-42

Roberts RJ, Johnson KA, Casten MT (2004) Control of Salmincola californiensis (Copepoda: Lernaeapodidae) in rainbow trout, Oncorhynchus mykiss (Walbaum): a clinical and histopathological study. J Fish Dis 27:73-79

Robinson M (1979) Efficacy of oxantel tartrate against Trichuris suis in swine. Vet Parasitol 5:223-235

> Robinson MW, Trudgett A, Hoey EM, Fairweather I (2002) Triclabendazole-resistant Fasciola hepatica: beta-tubulin and response to in vitro treatment with triclabendazole. Parasitology 124:325-338

Rodriguez JLT, Fernandez MTS (2001) Attempts at oral pharmacological treatment of Ichthyophthirius multifiliis in rainbow trout, Oncorhynchus mykiss (Walbaum). J Fish Dis 24:249-252

Rufener L, Kaminsky R, Mäser P (2009) In vitro selection of Haemonchus contortus for benzimidazole resistance reveals a mutation at amino acid 198 of beta-tubulin. Mol Biochem Parasitol 168:120-122

> Sanmartín Durán ML, Caamano-García F, Fernández Casal J, Leiro J, Ubeira FM (1989) Anthelminthic activity of praziquantel, niclosamide, netobimin and mebendazole against Bothriocephalus scorpii naturally infecting turbot (Scophthalmus maximus). Aquaculture 76:199-201

Santamarina MT, Tojo J, Ubeira FM, Quinteiro P, Sanmartín ML (1991) Anthelmintic treatment against Gyrodactylus sp. infecting rainbow trout Onchorhynchus mykiss. Dis Aquat Org 10:39-43

Santarém VA, Farias MR, Tostes RA (2005) Demodectic mange in fattening pigs in São Paulo, Brazil. Vet Parasitol 131:169-171

Saowakon N, Tansatit T, Wanichanon C, Chanakul W, Reutrakul V, Sobhon P (2009) Fasciola gigantica: anthelmintic effect of the aqueous extract of Artocarpus lakoocha. Exp Parasitol 122:289-298

Schalch SHC, Ruas de Moraes F, Soares VE (2009) Praziquantel, levamisol e diflubenzuron no controle de Dolops carvalhoi (Crustacea: Branchiura) e Anacanthorus penilabiatus (Monogenea: Dactylogyridae) em Piaractus mesopotamicus, Holmberg, 1887 (Osteichtyes: Characidae). Rev Bras Parasitol Vet 18:53-59

Schmahl G, Benini J (1998) Treatment of fish parasites. 11. Effects of different benzimidazole derivatives (albendazole, mebendazole, fenbendazole) on Glugea anomala, Moniez, 1887 (Microsporidia): ultrastructural aspects and efficacy studies. Parasitol Res 60:41-49

Schmahl G, Mehlhorn H (1985) Treatment of fish parasites. 1. Praziquantel effective against monogenean (Dactylogyrus vastator, Dactylogyrus extensus, Diplozoon paradoxum). Z Parasitenkd 71:727-737

> Schmahl G, Taraschewski H (1987) Treatment of fish parasites. 2. Effects of praziquantel, niclosamide, levamisole$\mathrm{HCl}$, and metrifonate on monogenea (Gyrodactylus aculeati, Diplozoon paradoxum). Parasitol Res 73:341-351

Schmidt J (1998) Effects of benzimidazole anthelmintics as microtubule-active drugs on the synthesis and transport of surface glycoconjugates in Hymenolepis microstoma, Echinostoma caproni, and Schistosoma mansoni. Parasitol Res 84:362-368

> Sevatdal S, Copley L, Wallace C, Jackson D, Horsberg TE (2005) Monitoring of the sensitivity of sea lice (Lepeophtheirus salmonis) to pyrethroids in Norway, Ireland and Scotland using bioassays and probit modelling. Aquaculture 244:19-27

> Shaikh B, Rummel N, Gieseker C, Chu PS, Reimschuessel R (2007) Residue depletion of tritium-labeled ivermectin in 
rainbow trout following oral administration. Aquaculture 272:192-198

Sharma S, Abuzar S (1983) The benzimidazole anthelmintics - chemistry and biological activity. Prog Drug Res 27:85-161

Shompole S, Yao C, Cheng X, Knox D, Johnson S, Jasmer DP (2002) Distinct characteristics of two intestinal protein compartments discriminated by using fenbendazole and a benzimidazole resistant isolate of Haemonchus contortus. Exp Parasitol 101:200-209

Sitjà-Bobadilla A, Conde de Felipe M, Alvarez-Pellitero P (2006) In vivo and in vitro treatments against Sparicotyle chrysophrii (Monogenea: Microcotylidae) parasitizing the gills of gilthead sea bream (Sparus aurata L.). Aquaculture 261:856-864

Slocombe JO, Heine J, Barutzki D, Slacek B (2007) Clinical trials of efficacy of praziquantel horse paste $9 \%$ against tapeworms and its safety in horses. Vet Parasitol 144: 366-370

Stoskopf MK (1993) Shark pharmacology and toxicology. In: Stoskopf MK (ed) Fish medicine. WB Saunders, Philadelphia, PA, p 809-816

Szekely C, Molnar K (1987) Mebendazole as an efficacious drug against pseudodactylogyrosis in the European eel (Angullla angullla). J Appl Ichthyology 3:183-186

Taraschewski H, Renner C, Mehlhorn H (1988) Treatment of fish parasites. 3. Effects of levamisole $\mathrm{HCl}$, metrifonate, fenbendazole, mebendazole, and ivermectin on Anguillicola crassus (nematodes) pathogenic in the air bladder of eels. Parasitol Res 74:281-289

Thienpont D, Vanparijs OFJ, Raeymaekers AHM, Vandenberk J and others (1966) Tetramisole (R 8299), a new, potent broad spectrum anthelmintic. Nature 209: 1084-1086

Tojo JL, Santamarina MT (1998) Oral pharmacological treatments for parasitic diseases of rainbow trout Oncorhynchus mykiss. II: Gyrodactylus sp. Dis Aquat Org 33: 187-193

Tojo J, Santamarina MT, Ubeira FM, Estevez J, Sanmartín ML (1992) Anthelmintic activity of benzimidazoles against Gyrodactylus sp. infecting rainbow trout Oncorhynchus mykiss. Dis Aquat Org 12:185-189

Tonguthai K (1997) Control of freshwater fish parasites: a Southeast Asian perspective. Int J Parasitol 27:1185-1191

Tracy JW, Webster LT (2001) Drugs used in the chemotherapy of helminthiasis. In: Gilman AG (ed) Goodman \& Gilman's

Editorial responsibility: Dieter Steinhagen,

Hannover, Germany
The pharmacological basis of therapeutics. McGraw-Hill, New York, NY, p 1121-1140

Tsechpenakis G, Bianchi L, Metaxas D, Driscoll M (2008) A novel computational approach for simultaneous tracking and feature extraction of $C$. elegans populations in fluid environments. IEEE Trans Biomed Eng 55:1539-1549

Tsibidis GD, Tavernarakis N (2007) Nemo: a computational tool for analyzing nematode locomotion. BMC Neurosci 8:86

USDA (United States Department of Agriculture) (2006) Census of aquaculture (2005). 2002 Census of Agriculture. USDA, Washington, DC. Available at www.agcensus. usda.gov/Publications/2002/Aquaculture/AQUACEN.pdf

> Várady M, Cernanská D, Corba J (2006) Use of two in vitro methods for the detection of anthelmintic resistant nematode parasites on Slovak sheep farms. Vet Parasitol 135: 325-331

- Várady M, Corba J, Letková V, Kovác G (2009) Comparison of two versions of larval development test to detect anthelmintic resistance in Haemonchus contortus. Vet Parasitol 160:267-271

Westcott JD, Stryhn H, Burka JF, Hammell KL (2008) Optimization and field use of a bioassay to monitor sea lice Lepeophtheirus salmonis sensitivity to emamectin benzoate. Dis Aquat Org 79:119-131

Williams JC, Broussard SB (1995) Comparative efficacy of levamisole, thiabendazole and fenbendazole against cattle gastrointestinal nematodes. Vet Parasitol 58:83-90

> Williams JC, Plue RE (1992) Efficacy of ivermectin delivered from a sustained-release bolus against inhibited early fourth-stage larvae of Ostertagia ostertagi and other nematodes in cattle. Am J Vet Res 53:793-795

Williams JC, Knox JW, Marbury KS, Swalley RA, Eddi CS (1991) Efficacy of levamisole against Ostertagia ostertagi in Louisana cattle during maturation of inhibited larvae (September) and during minimal inhibition (December/ January). Vet Parasitol 40:73-85

> Wolstenholme AJ, Rogers AT (2005) Glutamate-gated chloride channels and the mode of action of the avermectin/ milbemycin anthelmintics. Parasitology 131(Suppl): S85-S95

Xiao L, Saeed K, Herd LP (1996) Efficacy of albendazole and fenbendazole against Giardia infection in cattle. Vet Parasitol 61:165-170

Submitted: July 23, 2010; Accepted: October 15, 2010 Proofs received from author(s): February 18, 2011 